\title{
Developmental changes in localization of steroid synthesis enzymes in camelid placenta
}

\author{
F. B. P. Wooding ${ }^{1}$, M. Ozturk ${ }^{2}$, J. A. Skidmore ${ }^{3}$ and W. R. Allen ${ }^{4}$ \\ ${ }^{1}$ Physiology Department, Cambridge University, Downing Street, Cambridge CB2 3EG, UK; ${ }^{2}$ Medical \\ Faculty, Istanbul University, Istanbul, Turkey; ${ }^{3}$ Camel Reproduction Centre, PO Box 11808, Dubai, UAE; \\ and ${ }^{4}$ TBA Equine Fertility Unit, Mertoun Paddocks, Woodditton Road, Newmarket, Suffolk CB8 9BH, UK
}

The uninucleate trophoblast of epitheliochorial camelid placenta produces multinucleate giant cells starting between day 30 and day 35 of pregnancy. The giant cells are found scattered along the trophoblast at similar frequency throughout gestation. Light microscope immunocytochemistry indicates that the four steroid synthesis enzymes

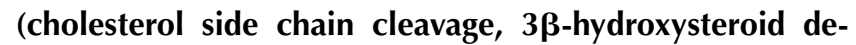
hydrogenase, $17 \alpha$-hydroxylase and aromatase) are present in all uninucleate trophoblast cells between day 14 and day 30 of pregnancy, but are found only in the giant cells once they are established, and that this localization persists until term. The giant cells show massive amounts of smooth endoplasmic reticulum and numerous small mitochondria, again as has been shown in other steroidproducing cells. As progesterone from the corpus luteum is necessary throughout gestation in camels, the capacity for oestrogen production by the trophoblast presumably has an important role, but one limited mostly to the immediate vicinity of the fetomaternal interface.

\section{Introduction}

One of the notable features of ungulate placentation is the range of structures from epitheliochorial to synepitheliochorial and the occurrence of specialized populations of trophoblast cells such as equine girdle cells, ruminant binucleate cells and camelid giant cells. These types of cell play important roles in underpinning the reproductive success of this enormous class of hoofed mammals. Their central economic importance to all human societies makes a detailed understanding of their reproductive processes essential to the optimal and humane manipulation of their populations.

Progesterone is essential for all mammalian pregnancies so far investigated. It is produced in either the corpus luteum or the placental trophoblast or both. Our previous assays of hormone production by camels have indicated that progesterone is probably produced by the corpus luteum and that the oestrogens are probably produced by the trophoblast (Skidmore et al., 1994, 1996a). Steroid production may be a generalized function of the whole trophoblast, as in human syncytiotrophoblast (Solomon, 1994; Wooding and Flint, 1994), or restricted to specialized regions, as in the giant cells of rodent placenta (Deane et al., 1962). The camel placenta is epitheliochorial: a simple apposition of trophoblast and uterine epithelium from implantation (day 12 after ovulation) to term (day 390 after mating), with no invasion by the trophoblast. Giant multinucleate

Email: fbpw2@cam.ac.uk cells develop in the trophoblast between day 30 and day 35 of pregnancy, and are found scattered through the trophoblast at a similar frequency throughout the remainder of gestation (Skidmore et al., 1996b). The presence of giant cells has been reported in the placentae of old (Van Lennep, 1963; Gorokhovski et al., 1975; Skidmore et al., 1996b; Jones et al., 2002) and new (Jones et al., 2002) world camelids, but the detailed structure and metabolic function of these cells has not been investigated. This paper reports an immunohistochemical and ultrastructural study of uninucleate and giant trophoblast cells throughout pregnancy in camelid placentae, which indicates that they are analogous to rodent giant cells in their capacity for steroid production. However, they are probably polyploid rather than having a single polytene nucleus and the steroids they secrete have to cross the uterine epithelium before they can diffuse into the maternal connective tissue and blood vessels. Despite these differences, both are in the best position, given the differences in the placental structure, to facilitate immunological camouflage and other functions by maintaining a high local concentration of steroids to ensure a successful pregnancy and uncomplicated delivery. Aspects of this work have been reported previously in an abstract (Ozturk et al., 1999).

\section{Materials and Methods}

Follicular growth was monitored in dromedary camels by ultrasonography and when a suitably mature follicle $(>1.5 \mathrm{~cm}$ in diameter; Skidmore et al., 1996c) was 

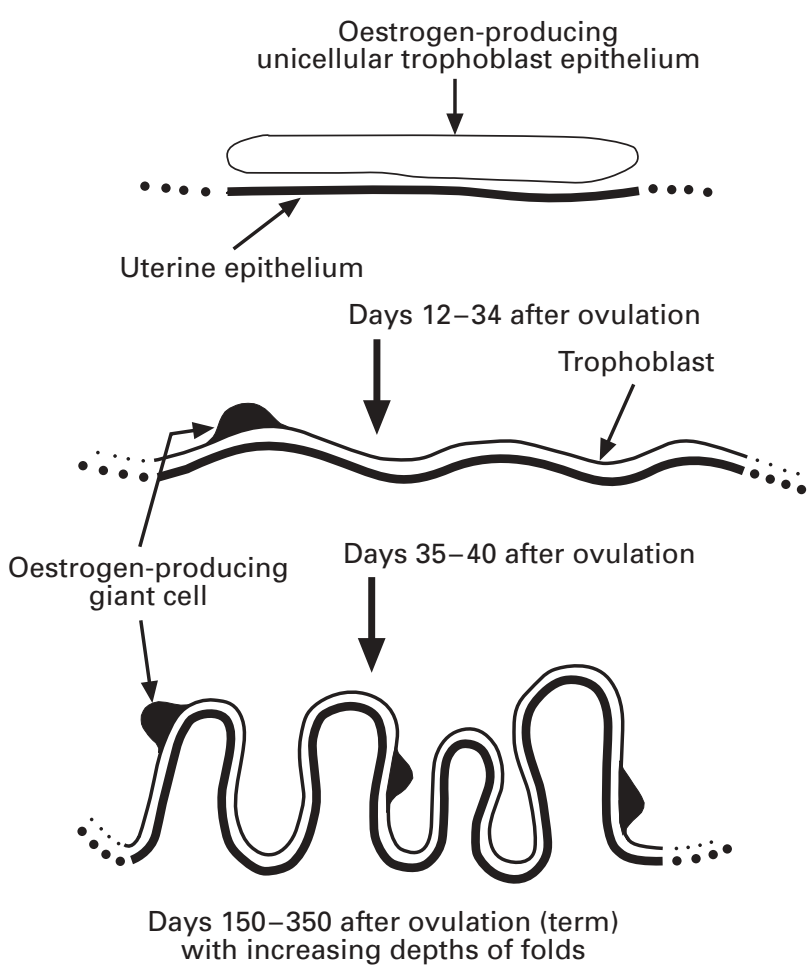

Fig. 1. Diagrammatic representation of the camelid giant cell and placental development. The thin line represents the trophoblast, initially forming an elongated blastocyst; the thick line represents the uterine epithelium.

present in one ovary the camel was injected with $\mathrm{GnRH}$ (Buserelin; Receptal; Hoechst Animal Health, Milton Keynes) to ensure that ovulation coincided with mating. This method produced accurately dated fetuses.
The camels were killed on days 14, 25, 35, 56, 155, 247 and 365 after ovulation by a barbiturate overdose and the placenta was immediately perfused or immersion-fixed in $3 \%(\mathrm{v} / \mathrm{v})$ glutaraldehyde- $3 \%(\mathrm{v} / \mathrm{v})$ formaldehyde in $0.1 \mathrm{~mol}$ phosphate buffer $\mathrm{I}^{-1}, \mathrm{pH} 7.2$. These techniques are described in detail in Skidmore et al. (1996b). All procedures were carried out in accordance with the ethical principles for animal research as specified in the UK Animals (Scientific Procedures) Act (1986). In addition, samples of freshly delivered term placentae from three camels as well as term placentae from normal pregnancies of Ilamas and alpacas were collected (H. D. Warner, Thorpe Morieux, Sudbury and M. Fisher, Agresearch, Ruakura Research Centre, Hamilton). Tissue samples were fixed for a minimum of $2 \mathrm{~h}$ and stored in a phosphate buffer at $4^{\circ} \mathrm{C}$ until processed. Samples for immunocytochemistry were embedded without further fixation in Lowicryl K4M resin (Agar Scientific, Stansted) at $-20^{\circ} \mathrm{C}$, whereas samples for ultrastructural investigation were processed through $1 \%(\mathrm{w} / \mathrm{v})$ osmium tetroxide in phosphate buffer before embedding at room temperature $\left(20^{\circ} \mathrm{C}\right)$ in Araldite (see Wooding et al., 1996, 2000). Semithin sections from K4M blocks were picked up on polylysine-coated coverslip fragments, dried at $60^{\circ} \mathrm{C}$ for $30 \mathrm{~min}$, and floated for $10 \mathrm{~min}$ on PBS containing $1 \%(\mathrm{w} / \mathrm{v})$ BSA and $0.05 \%(\mathrm{w} / \mathrm{v})$ Thimerosal (Sigma, Poole; this solution was used for all the antibody dilutions). The sections were transferred on to a drop of rabbit polyclonal antibody, incubated overnight at $4^{\circ} \mathrm{C}$, jetwashed with PBS and incubated for $30 \mathrm{~min}$ on goat anti-rabbit IgG4 $\mathrm{nm}$ gold colloid (Jackson Immunoresearch Labs: from Stratech Scientific Ltd, Luton). After the immunoreaction, the sections were jetwashed with PBS and glass-distilled water (GDW) and left on

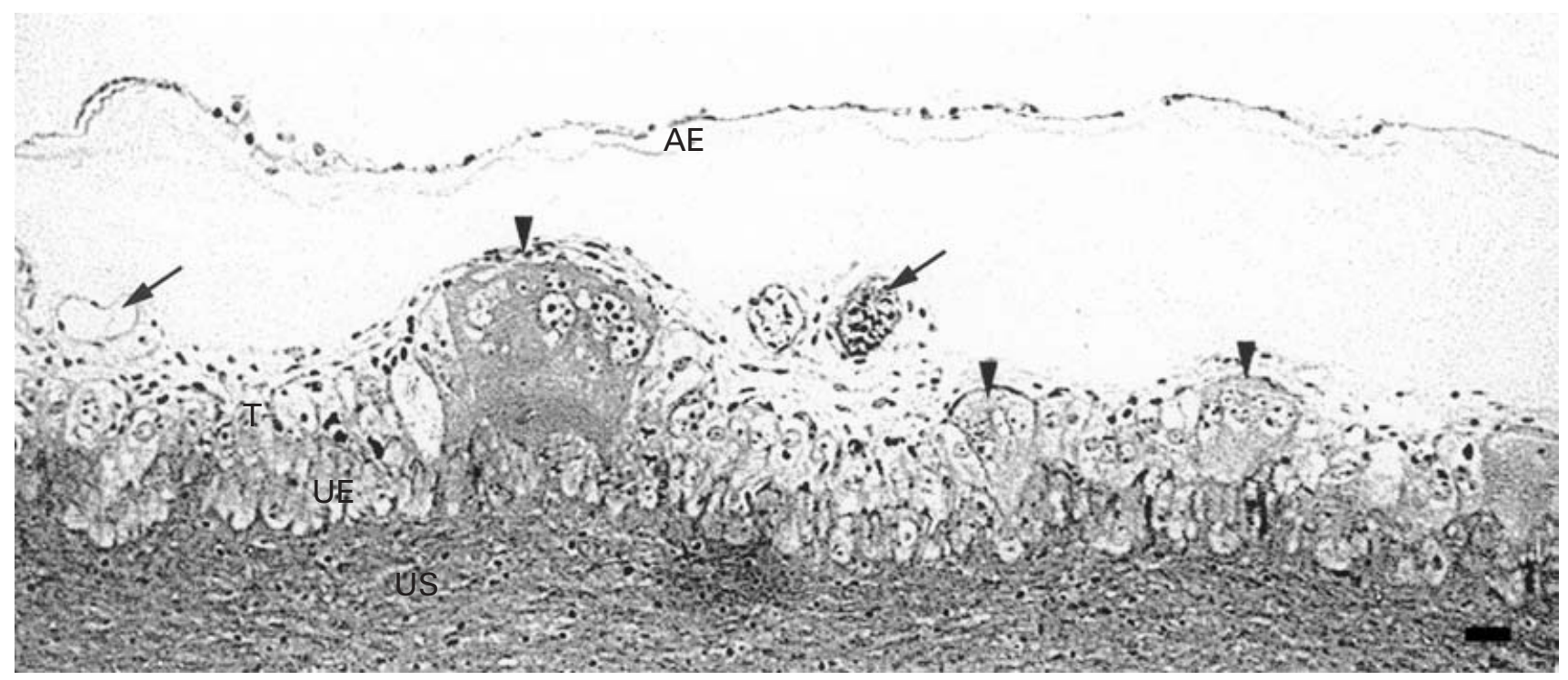

Fig. 2. Light micrograph of camel placenta at day 35 after ovulation. Note the giant cells (arrowheads) in the trophoblast (T), which is apposed to the uterine epithelium (UE) and underlying uterine stroma (US). The separation of the allantoic epithelium (AE) from the allantoic mesenchyme with its fetal blood vessels (arrows) is an artefact. Scale bar represents $10 \mu \mathrm{m}$. 


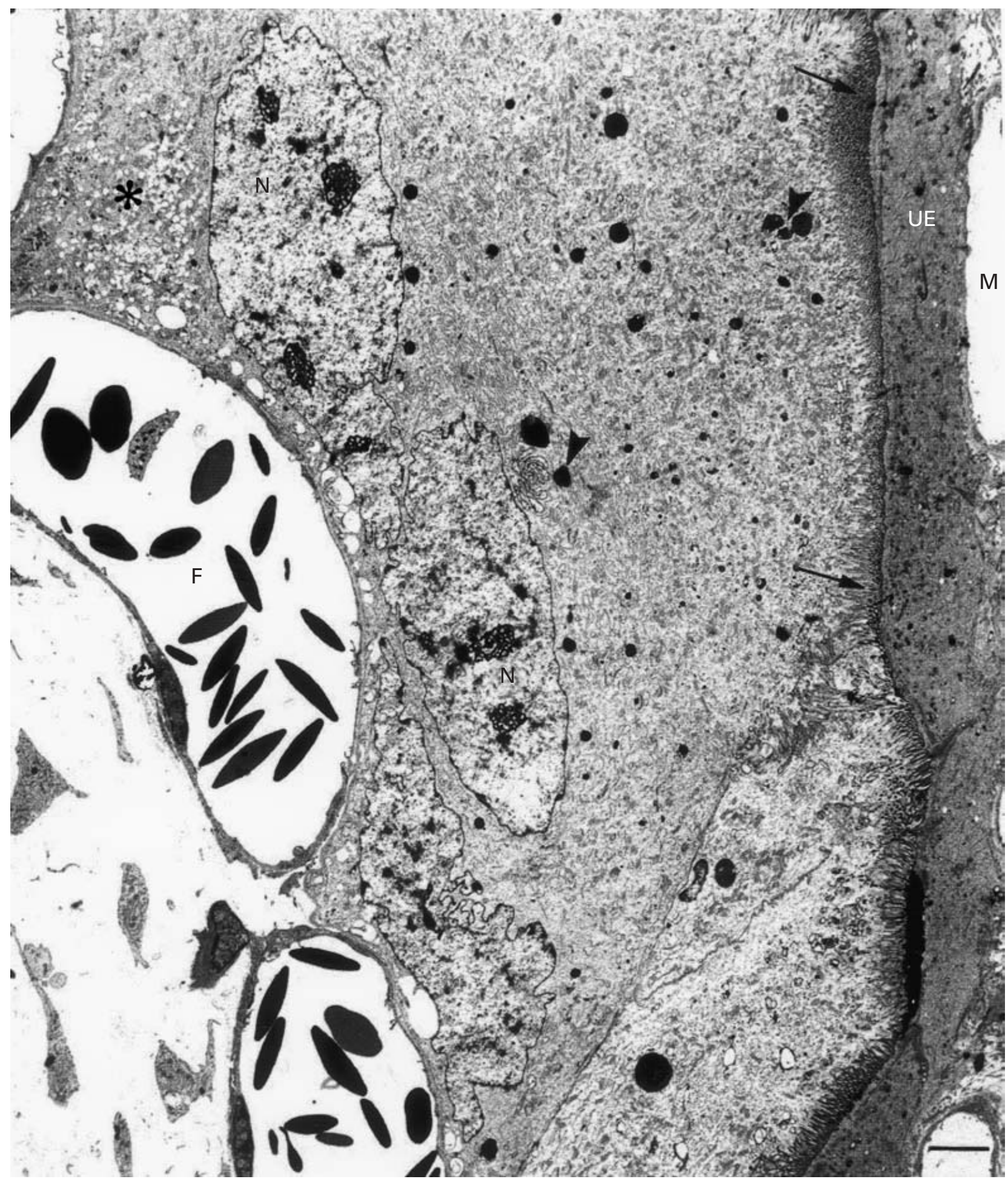

Fig. 3. Electron micrograph of a camel giant cell with three eccentric nuclear profiles at day 166 after ovulation. Lysosomes (arrowheads) are scattered throughout the cytoplasm and there is an area containing numerous tiny lipid droplets basally (asterisk), as well as fetal (F) and maternal (M) blood vessels. The microvillar junction (arrows) is intact, formed from an interdigitation between the microvilli of the giant cell with the microvilli of the thin uterine epithelial cells (UE). N: nucleus. Scale bar represents $10 \mu \mathrm{m}$. 


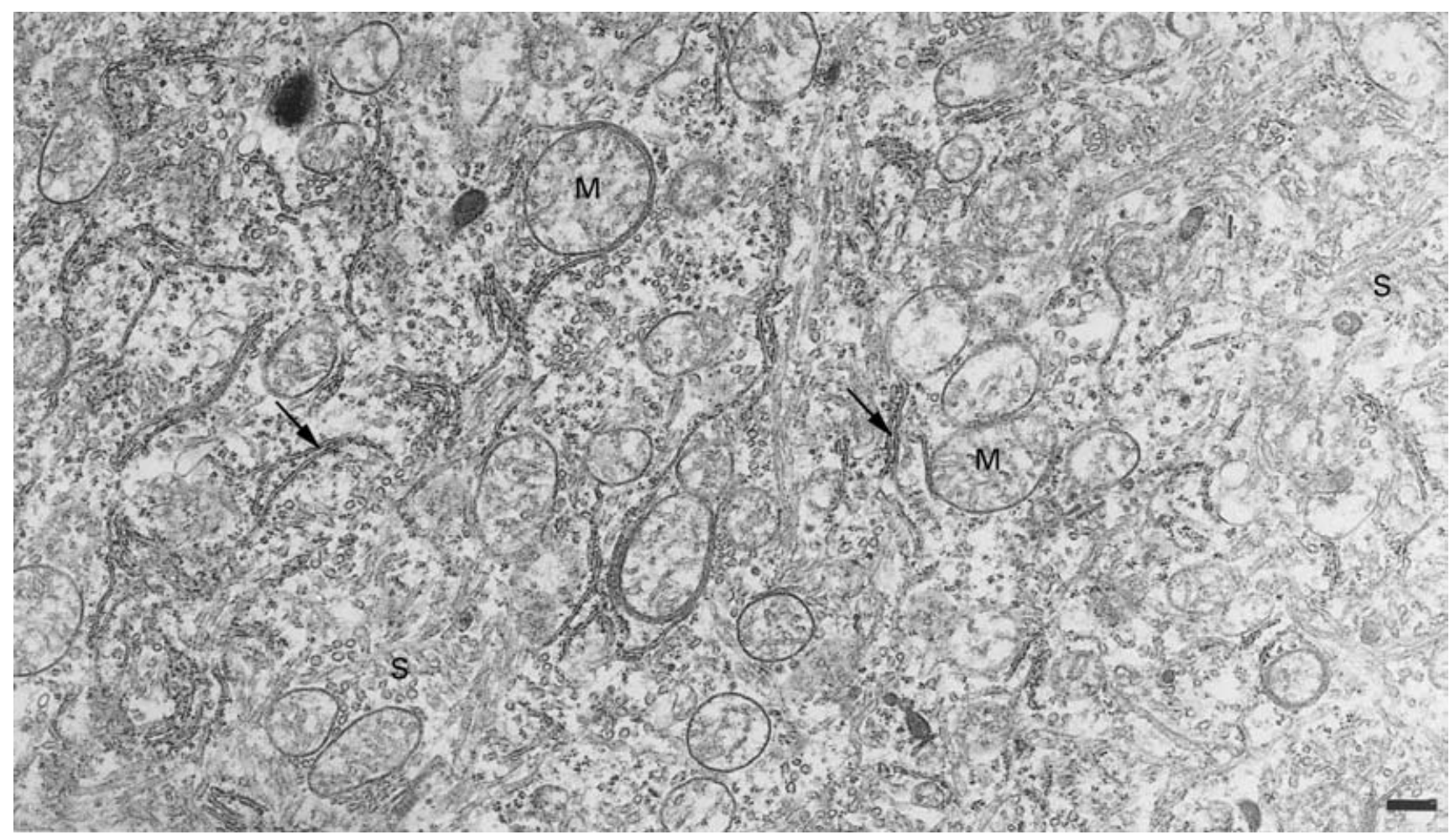

Fig. 4. Detail of the apical cytoplasm of a giant cell from camel placenta at day 35 after ovulation. Note the numerous mitochondria (M), frequent tubules and vesicles of smooth endoplasmic reticulum (S), and occasional cisternae of rough endoplasmic reticulum (arrows). This pattern of ultrastructure is found in the giant cells throughout gestation. Scale bar represents $1 \mu \mathrm{m}$.

GDW for 10 min before incubation for 10-20 min on the gold intensification reagent (Amersham International, Aylesbury). All the incubations after the polyclonal antibody step were at room temperature. The coverslip pieces were finally jetwashed with GDW, dried and mounted with Biomount (Biocell International, Cardiff).

For electron microscopy, ultrathin sections on nickel grids or celloidin-covered $2 \mathrm{~mm} \times 1 \mathrm{~mm}$ slotted supports were treated as above but using $15 \mathrm{~nm}$ gold colloid without intensification, and finally stained with uranyl acetate and lead citrate. Controls omitting the primary antibody or substituting it with an irrelevant antibody were all negative.

\section{Steroid synthesis enzyme antibodies}

Polyclonal rabbit antibodies were raised against: (i) bovine adrenal cholesterol side chain cleavage (SCC) enzyme (M. R. Waterman, Biochemistry Dept, Texas University, Dallas, TX), used at 1 in 100 dilution; (ii) human placental $3 \beta$-hydroxysteroid dehydrogenase (3ß-HSD; J. I. Mason; see Lorence et al., 1990), used at 1 in 100 dilution; (iii) pig testicular $17 \alpha$-hydroxylase (A. Payne; see Hales et al., 1987), used at 1 in 100 dilution; and (iv) human placental aromatase (N. Harada; see Naganuma et al., 1990), used at 1 in 100 dilution.

\section{Results}

The camel placenta is epitheliochorial, a simple apposition of trophoblast to uterine epithelium, with interdigitation of microvilli by day 25 after ovulation. Giant cells with a large or multiple nuclei develop by day 35 after ovulation in the previously uninuclear trophoblast and considerable numbers are found scattered throughout the placenta during subsequent gestation (Figs 1-3). The giant cell cytoplasm has many small mitochondria (Fig. 4), but the predominant organelle apically is smooth endoplasmic reticulum (SER) tubules and vesicles throughout the cytoplasm, frequently in large groups (Fig. 4). There is a zone above the nuclei where small Golgi stacks are concentrated (Fig. 5a) among the SER and there are occasional rough endoplasmic reticulum (RER) cisternae scattered throughout the cytoplasm. As pregnancy progresses, areas of giant cell cytoplasm with numerous lipid droplets are found with arrays of RER, the cisternae of which are wrapped closely around the lipid droplets (Fig. 5b). In each giant cell there is usually more than one nuclear profile; some may be bizarrely multilobed (Figs 2 and 3; see also Fig. 10, Skidmore et al., 1996b). A limited serial section check showed that most of the profiles are interconnected, which is indicative of the presence of only one nucleus per giant cell, but this needs more exact investigation. This pattern of organelles shows no obvious changes during gestation. There is no 

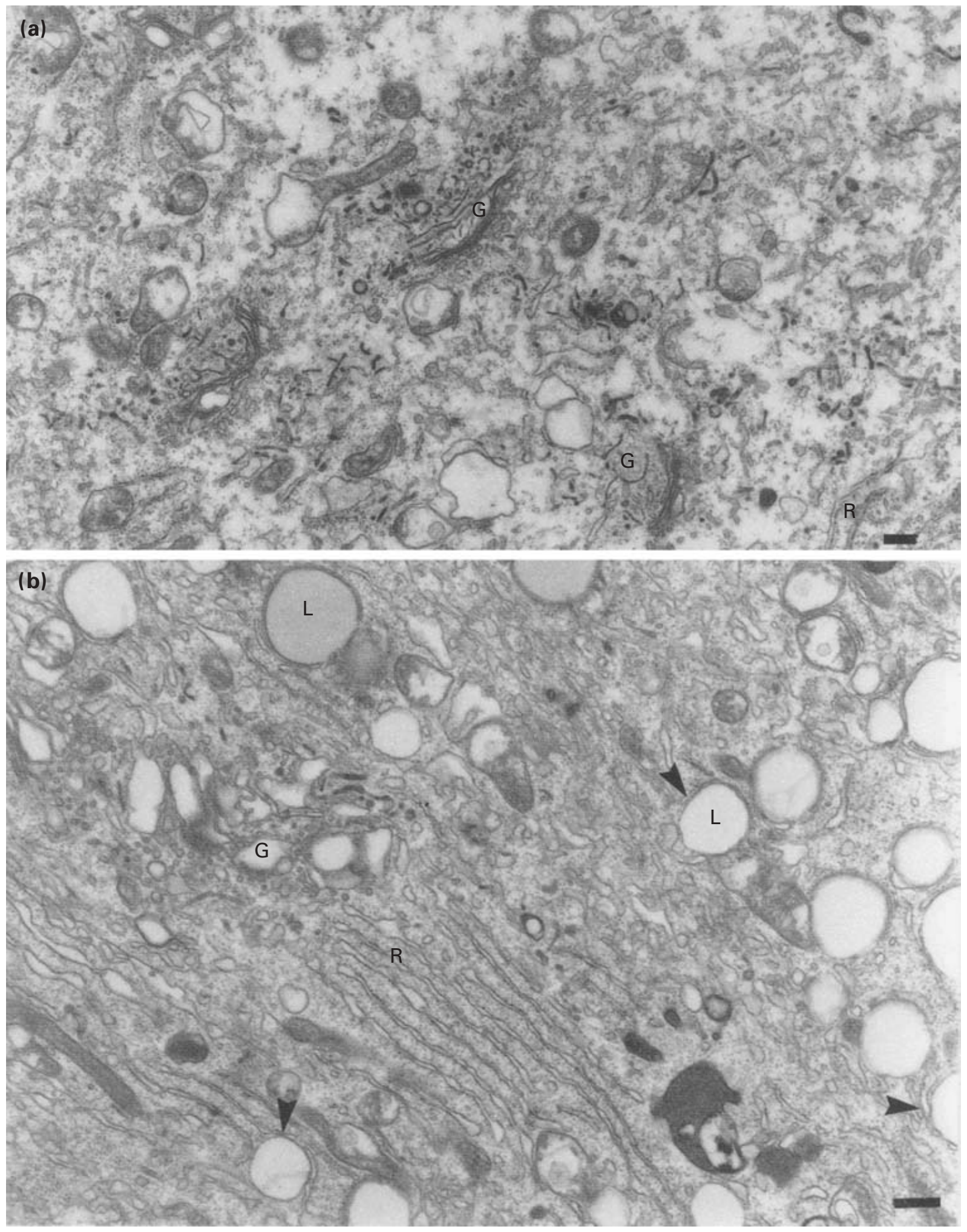

Fig. 5. Camel placenta at day 56 after ovulation. (a) Frequent small Golgi stacks (G) in a zone above the nucleus are characteristic of giant cells at all stages of gestation. Most of the small vesicles in between are smooth endoplasmic reticulum; rough endoplasmic reticulum cisternae $(\mathrm{R})$ are rare in this region. (b) Cytoplasmic areas with numerous tiny lipid droplets (L) and arrays of rough endoplasmic reticulum cisternae (R), some of which are closely associated with the lipid (arrowheads), increase in frequency as gestation progresses. An occasional Golgi stack $(G)$ may also be seen in this area. Scale bars represent $1 \mu \mathrm{m}$. 
<smiles>CCCCC1CCC2C1CCC1C3CCC(O)C=C3CCC12</smiles><smiles>CC(=O)C1CCC2C1CCC1C3CCC(C(=O)O)=C3CCC12</smiles><smiles>CC(=O)C1CCC2C1CCC1C3CCCC(C(=O)O)=C3CCC12</smiles>

Progesterone

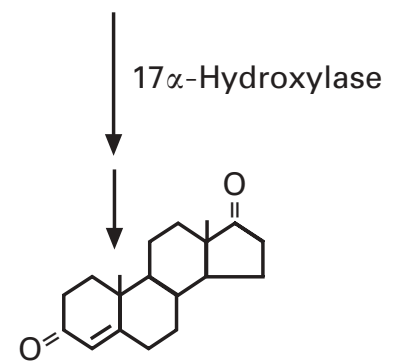

Androstenedione

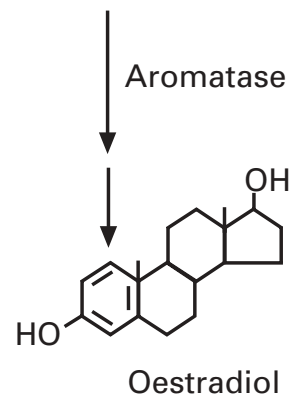

Fig. 6. Sequence of oestrogen synthesis from cholesterol.

indication of any phagocytic activity by giant cells, with only a few small lysosomes scattered throughout or at the base of the cells. The uninucleate trophoblast cells (UNCs) have many more RER cisternae than do giant cells, but have fewer SER membranes. They have a single, usually spherical nucleus, a supranuclear Golgi body
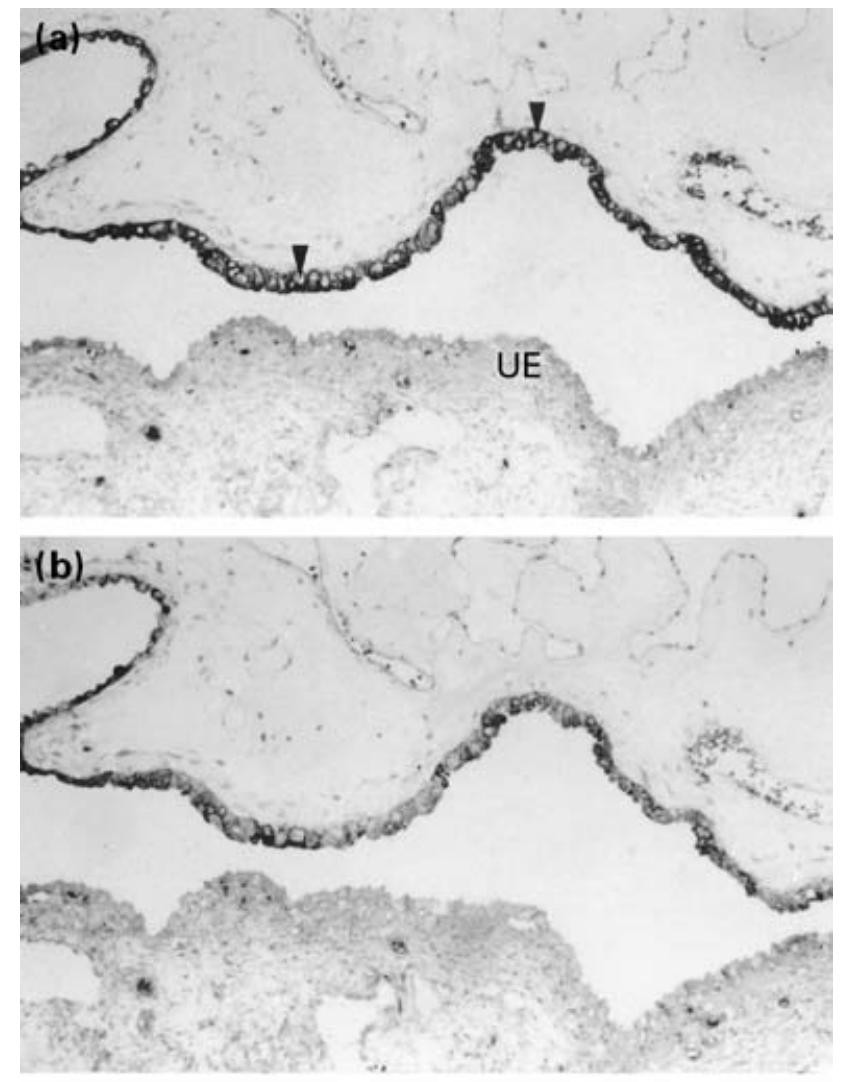

(c)

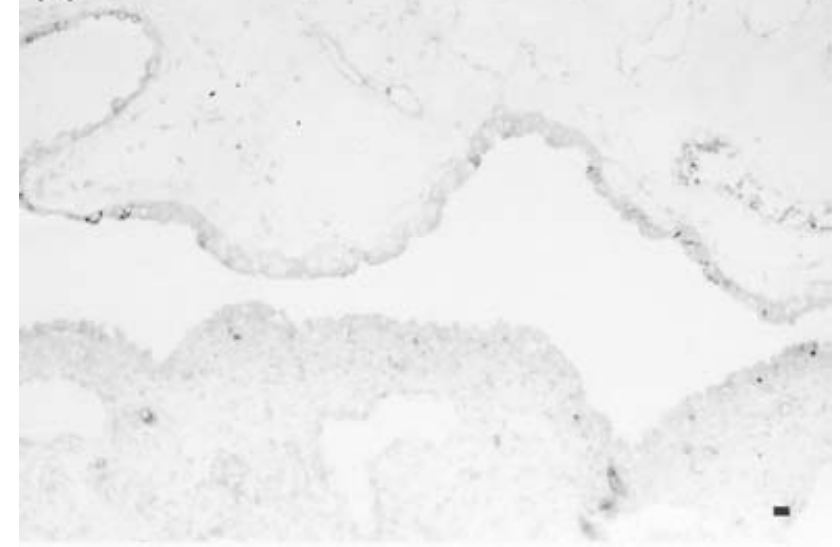

Fig. 7. Camel placenta at day 25 after ovulation. Immunocytochemical demonstration of (a) $17 \alpha$-hydroxylase and (b) aromatase activity in trophoblast cytoplasm only; nuclei are negative (arrowheads). The separation of trophoblast from uterine epithelium (UE) is a processing artefact. Side chain cleavage and $3 \beta$-hydroxysteroid dehydrogenase ( $3 \beta-\mathrm{HSD}$ ) gave similar localization. (c) The control omitted steroid antibody from the processing sequence. Scale bar represents $10 \mu \mathrm{m}$.

and mitochondria scattered throughout the cells. Unlike the giant cells, the UNCs have many lysosomal profiles, usually basal to the nucleus, and a meshwork of vesicles and tubules immediately under the apical microvilli, which is probably involved in nutrient uptake to the fetus. 

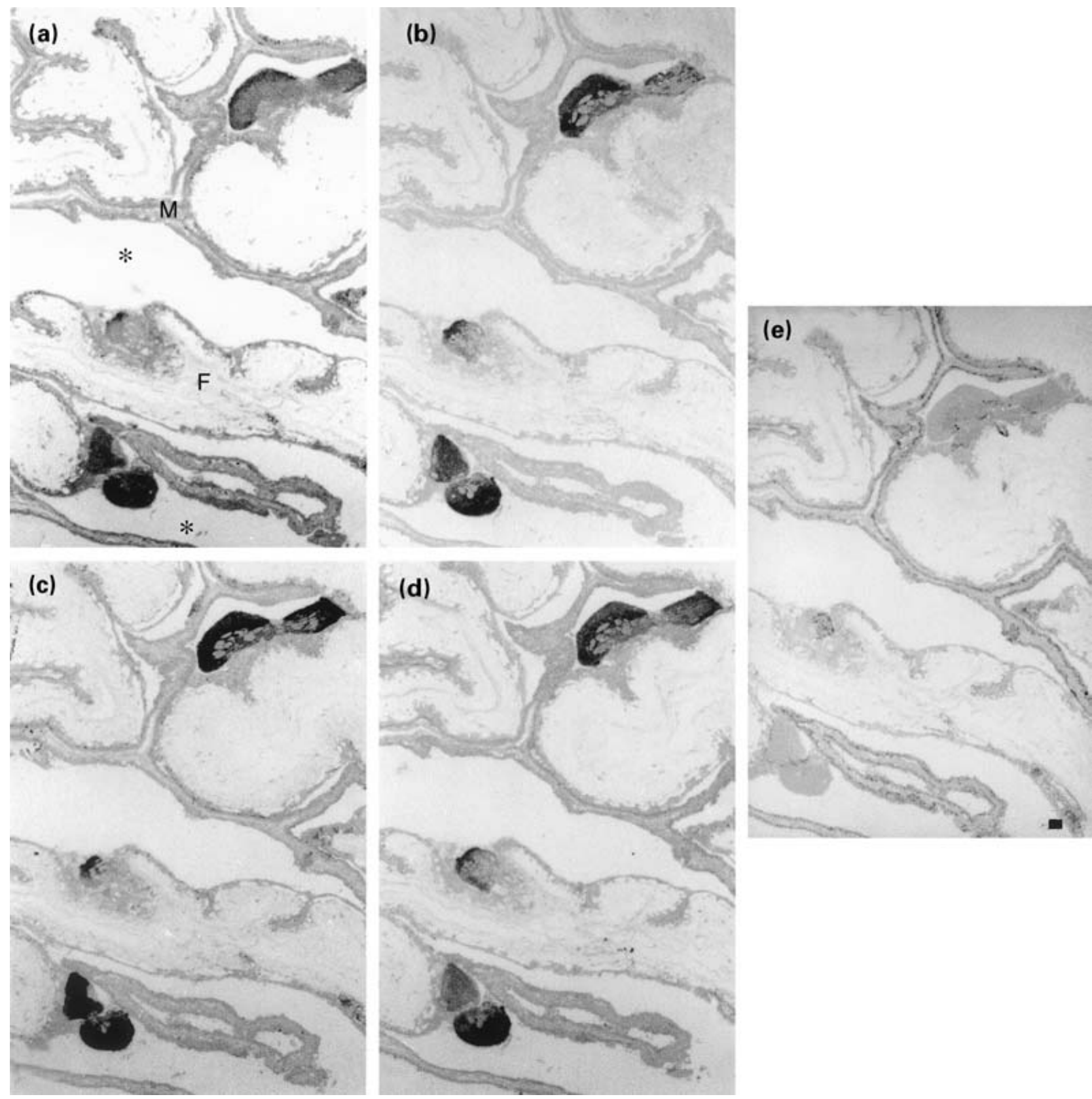

Fig. 8. Camel placenta at day 250 after ovulation. Immunocytochemical demonstration of the presence of all four enzymes (a) $3 \beta$ hydroxysteroid dehydrogenase, (b) 17 $\alpha$-hydroxylase, (c) side chain cleavage and (d) aromatase required for the conversion of cholesterol to oestradiol in the cytoplasm of the same giant cells on serial sections. (e) Control section. The fetal villous stroma (F) has a much larger volume than the maternal $(\mathrm{M})$; the separations (asterisks) between the two are processing artefacts. Scale bar represents $10 \mu \mathrm{m}$.

Antibodies to the four enzymes on the cholesterol to oestradiol synthetic pathway (Fig. 6) were used to localize steroid production capacity. SCC, $3 \beta-\mathrm{HSD}, 17 \alpha-$ hydroxylase and aromatase immunoreactivities were found only in the uninucleate trophoblast cell cytoplasm from day 14 to day 25 after ovulation (Fig. 7). The earliest that giant cells were found in the camel trophoblast was on day 30 after ovulation. At this time some of the uninucleate trophoblast was positive for the four enzymes but the giant cells expressed the enzymes far more strongly. From day 35 after ovulation up to and including the delivered placenta at term, the enzyme immunoreactivities were found only in the giant cell cytoplasm (Fig. 8). All control sections were negative. Samples of term placenta from camels, Ilamas and alpacas showed similar ultrastructure and steroid enzyme 

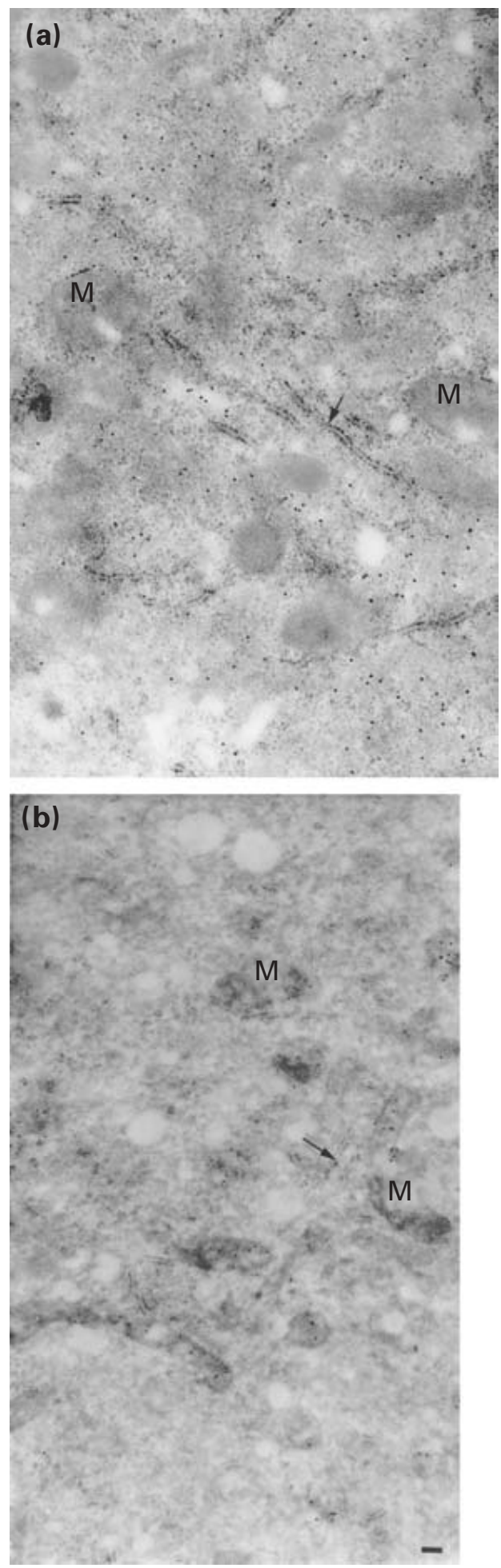

Fig. 9. Camel placenta at day 56 after ovulation. Immunoultrastructural demonstration of the localization of (b) side chain cleavage (SCC) activity to the mitochondria (M) and (a) $17 \alpha$ hydroxylase to the smooth endoplasmic reticulum, which does not stain with this plastic embedding but occupies all the space between the mitochondria and rough endoplasmic reticulum (arrows) (compare with Fig. 4). This localization is as demonstrated for other steroid synthesizing tissues. Scale bar represents $1 \mu \mathrm{m}$. localizations restricted to the giant cells. Investigation under the electron microscope showed the localization of SCC to the mitochondria (Fig. 9) and the localization of $17 \alpha$-hydroxylase to the SER regions of the cytoplasm (Fig. 9), as has been shown in other steroidogenic tissues (Rumsby, 1997).

\section{Discussion}

This study shows for the first time that all of the enzymes necessary for the cholesterol to oestrogen conversion can be localized in dromedary camel conceptus from day 14 after ovulation. All mammalian pregnancies require the conceptus to signal to the mother early in implantation to maintain progesterone secretion from the corpus luteum of pregnancy and production of oestrogen by day 14 after ovulation would be early enough to serve as the fetal signal to trigger a successful pregnancy. Subsequent trophoblast differentiation to produce steroidsynthesizing giant cells coincides with the loss of the steroid enzymes from the mostly uninucleate population and also with an increase in the oestrogen concentration in maternal blood between day 30 and day 70 after ovulation (Skidmore et al., 1996a). The light microscope immunocytochemical results are reinforced by the electron microscope observations, showing that the SCC and $17 \alpha$-hydroxylase immunoreactivities are localized to the mitochondria and SER, respectively, as has been shown in other steroid-producing tissues (for a review, see Rumsby, 1997). The predominance of SER and the occurrence of numerous tiny lipid droplets with intimate ER association also emphasizes the similarity with the ultrastructure of the cells of the adrenal gland and corpus luteum, which are specialized for steroid synthesis.

All the camelids investigated in the present study have giant cells of similar structure, and camel, Ilama and alpaca giant cells all show immunoreactivities for the four steroidogenic enzymes (results not shown). The ultrastructure and immunocytochemical reactions of the giant cells are essentially similar at all of the stages examined, including those in the term placentae. Unfortunately there are as yet no accurate counts of the frequency of camelid giant cells. Anecdotal reports are inconsistent: '.. in the second half of pregnancy [in camel] there are fewer than previously, but one had many...' (Van Lennep, 1963); the Bactrian camel has '... most at 9 months of gestation...' (Gorokhovski, 1975); and alpacas are reported to have '... many more than camels...' and they '... increase in number and size during gestation...' (Jones et al., 2002). Our limited observations indicate a similar frequency per unit length of trophoblast epithelium throughout pregnancy in dromedary camels, but an accurate morphometric study is required.

In camels, removal of the corpus luteum, whether chemical or surgical, necessitates progesterone supplementation to maintain pregnancy at any stage of 
gestation (Skidmore et al., 1994), indicating that the synthesis of steroids by the placental giant cells is obviously insufficient to compensate for the loss of production by the corpus luteum. However, this capacity for steroidogenesis close to the fetomaternal interface may be important to maintain high concentrations of steroids at this position. Furthermore, as only SCC and $17 \beta-\mathrm{HSD}$ are necessary for progesterone synthesis, the presence of $17 \alpha$-hydroxylase and aromatase activities may indicate a need for localized placental oestrogen for a successful camelid pregnancy. The first formation of giant cells correlates well with the increase in circulating oestrogen concentration between day 30 and day 70 of pregnancy (Skidmore et al., 1994), but it remains to be established whether the further considerable increase in oestrogen concentration from day 300 onward correlates with an increase in the number or activity of giant cells, or whether the increase comes from a separate source.

The authors are grateful to H. D. Warner, Thorpe Morieux, Sudbury and M. Fisher Agresearch, New Zealand for providing samples of Ilama and alpaca placentae. The authors are also very grateful for the generous gift of antibodies from M. R. Waterman, A. Payne, J. I. Mason and N. Harada.

\section{References}

Deane HW, Rubin B, Driks EC, Lobel B and Leipsner G (1962) Trophoblast giant cells in the placentae of rats and mice and their probable role in steroid hormone production Endocrinology 70 407-419

Gorokhovski NL, Schmidt GA, Shagneun VG and Beptidanova YP (1975) Giant cells in the placenta of the Bactrian camel (in Russian) Archives Anatomia Histologica et Embriologica 19 41-44

Hales DB, Sha L and Payne AH (1987) Testosterone inhibits cAMP induced de novo synthesis of Leydig cell P450 17 $\alpha$ hydroxylase by an androgen receptor mediated mechanism Journal of Biological Chemistry 262 $11200-11206$

Jones CJP, Abdelnaeim M, Bevilacqua E, Olivera L and Leiser R (2002) Comparison of uteroplacental glycosylation in the camel (Camelus dromedarius) and alpacas (Lama pacos) Reproduction 123 115-126
Lorence MC, Murry BA, Trant AM and Mason JI (1990) Human $3 \beta$-hydroxysteroid dehydrogenase from placenta: expression in nonsteroidogenic cells of a protein that catalyses the dehydrogenation/ isomerisation of C19 and C21 steroids Endocrinology 126 2493-2498

Naganuma H, Ohtani H, Harada N and Nagura H (1990) Immunoelectron microscope localisation of aromatase in human placenta and ovary using microwave fixation Journal of Histochemistry and Cytochemistry 38 1427-1432

Ozturk M, Skidmore J, Allen WR and Wooding FBP (1999) Developmental changes in localisation of steroid synthesis in the camel placenta Journal of Physiology 517 32P

Rumsby G (1997) Molecular biology of steroid biosynthesis. In Molecular Endocrinology pp 179-202 Eds G Rumsby and SM Farrow. Bios Scientific Publishers, Oxford

Skidmore JA, Allen WR and Heap RB (1994) Oestogen synthesis by the peri-implantation conceptus of the one humped camel Journal of Reproduction and Fertility 101 363-371

Skidmore JA, Billah M and Allen WR (1996a) Patterns of hormone secretion through pregnancy in the one humped camel Reproduction, Fertility and Development 8 868-869

Skidmore JA, Wooding FBP and Allen WR (1996b) Implantation and early placentation of the one humped camel Placenta 17 253-262

Skidmore JA, Billah M and Allen WR (1996c) The ovarian follicular wave pattern and induction of ovulation in the mated and non-mated one humped camel (Camelus dromedarius) Journal of Reproduction and Fertility 106 185-192

Solomon S (1994) The primate placenta as an endocrine organ. In The Physiology of Reproduction pp 863-874 Eds E Knobil and JD Neill, Raven Press, New York

Van Lennep EW (1963) The placenta of the one humped camel during the second half of gestation Acta Morphologica Neerlandica Scandinavica $6373-379$

Wooding FBP and Flint APF (1994) Placentation. In Marshall's Physiology of Reproduction pp 230-420 Ed. G Lamming. Chapman and Hall, London

Wooding FBP, Morgan G, Jones GV and Care AD (1996) Calcium transport and the localisation of Calbindin-D9k in the ruminant placenta during the second half of pregnancy Cell Tissue Research 285 477-484

Wooding FBP, Morgan G, Fowden AL and Allen WR (2000) Separate sites and mechanisms for placental transport of calcium, iron and glucose in the equine placenta Placenta 22 635-645

Received 19 February 2003.

First decision 28 March 2003.

Revised manuscript received 3 April 2003.

Accepted 19 May 2003. 